\title{
Therapeutic efficacy of low dose (Dhaka regimen) versus high dose (Pritchard regimen) magnesium sulphate for management of eclampsia and impending eclampsia
}

\author{
Nisha Bhagat*, Preet Kamal Bedi, Davinder Pal, Arunima Saini
}

Department of Obstetrics and Gynecology, Government Medical College, Amritsar, Punjab, India

Received: 28 March 2018

Accepted: 30 April 2018

*Correspondence:

Dr. Nisha Bhagat,

E-mail: nishabhagat07@yahoo.com

Copyright: () the author(s), publisher and licensee Medip Academy. This is an open-access article distributed under the terms of the Creative Commons Attribution Non-Commercial License, which permits unrestricted non-commercial use, distribution, and reproduction in any medium, provided the original work is properly cited.

\begin{abstract}
Background: To compare the efficacy of low dose (Dhaka regimen) vis-a vis high dose (Pritchard regimen) magnesium sulphate in management of eclampsia and impending eclampsia.

Methods: The open-label, comparative study was conducted on 90 pregnant patients. They were admitted to emergency Department of Obstetrics and Gynaecology, Government Medical College, Amritsar with eclampsia or impending eclampsia. 10 patients dropped out at various stages of study and finally, 80 were enrolled and randomized (1:1 ratio) into two groups. Group-1, $\mathrm{N}=40$ were given low dose $\mathrm{MgSO}_{4}$ (Dhaka regime) and Group-2, $\mathrm{N}=40$ were given high dose $\mathrm{MgSO}_{4}$ (Pritchard). Termination of pregnancy was done as per Bishop's score, gestation age, maternal and fetal status. Primary outcome measure was therapeutic efficacy of equivalence for control of seizures whereas secondary outcome was adverse side-effects of both the regimens.

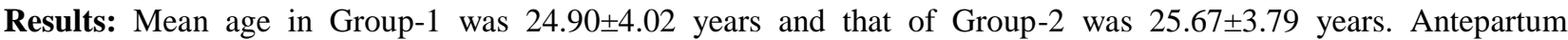
eclampsia was the most common diagnosis among groups i.e., 47.5\% and 55\% respectively. After treatment, the seizure control was $97.5 \%$ in Group- 1 and $100 \%$ in Group- 2 with comparable results $\left(x^{2}=1.013 ; p=0.314\right)$. However, highly significant difference was observed among dosage of $\mathrm{MgSO}_{4}$ that was required for control of seizure $(23.75 \pm 2.71 \mathrm{gm}$ versus $41.35 \pm 4.76 \mathrm{gm}$; $\mathrm{p}<0.001)$. Group-1 showed lower incidence of side-effects that is, loss of deep tendon reflex as compared to Group-2, but neonatal outcomes were comparable in both groups.

Conclusions: Low dose (Dhaka regimen) was equally effective in control of seizures as compared to high dose (Pritchard regimen) with lower incidence of side-effects.
\end{abstract}

Keywords: Dhaka regimen, Eclampsia, Magnesium sulphate $\left(\mathrm{MgSO}_{4}\right)$, Pritchard regimen

\section{INTRODUCTION}

Eclampsia is derived from the Greek word meaning flash of lightening, to shine forth. It is defined as the occurrence of generalized tonic-clonic convulsion in women with pre-eclampsia not caused by any other neurological or medical disorders. It is one of the most common obstetrical emergencies in developing countries causing significant maternal and perinatal morbidity and mortality. Incidence of eclampsia is 1 in 2000 deliveries in developed countries and 1 in 50 to 500 deliveries in developing countries. ${ }^{1}$ In India, the incidence of eclampsia ranges from 6 to100 per 10,000 live births. ${ }^{2}$ It accounts to $12 \%$ of maternal deaths worldwide as compared to $8 \%$ in India. $^{3}$ The worldwide estimated eclampsia deaths per year is $50,000 .{ }^{4}$

The principle management for eclampsia is control of convulsions along with supportive life measures and termination of pregnancy. Magnesium sulphate $\left(\mathrm{MgSO}_{4}\right)$ 
is the first-line drug for eclampsia, which acts by reducing presynaptic release of glutamate neurotransmitter, by blocking glutaminergic N-methyl-Daspartate (NMDA) receptors and calcium entry via voltage gated ionic channels. ${ }^{5}$ Various regimens are followed for management but Pritchard regimen is the most commonly used. The efficacy of $\mathrm{MgSO}_{4}$ in severe preeclampsia and eclampsia is time tested in various studies. However, because of its narrow therapeutic index, toxic side-effects are the major area of concern in clinical use. Its safety and toxicity was recently reviewed by Smith and coworker; more than 9500 women were treated, overall rate of absent patellar reflexes was $1.6 \%$, respiratory depression $1.3 \%$ and calcium gluconate administration $0.2 \% .^{6}$

Pritchard et al suggested that the dose of $\mathrm{MgSO}_{4}$ should be limited in women who are known to be or appear to be small. ${ }^{7}$ Women in India, especially from rural areas or from low socio-economic strata tend to have smaller body weight. Administrating Pritchard regime might prove to be hazardous in these low weight women and there is possibility of most dreadful respiratory failure. ${ }^{8}$ Reducing $\mathrm{MgSO}_{4}$ toxicity without compromising its efficacy in controlling seizures and lowering mortality rates remains a major challenge. ${ }^{9}$ A study conducted by Begum et al on women with low Body mass index (BMI) in Dhaka explains the efficacy of low dose regimen in controlling fits. ${ }^{10}$

Therefore, the present study aimed to measure efficacy of low dose $\mathrm{MgSO}_{4}$ (Dhaka regimen) as compared to high dose $\mathrm{MgSO}_{4}$ (Pritchard regimen) in control of convulsion in preeclampsia and eclampsia patients.

\section{METHODS}

It was a comparative, randomized study conducted in emergency Department of Obstetrics and Gynaecology of Government Medical College, Amritsar, Punjab on patients with eclampsia or features of impending eclampsia. Cases who had already received either magnesium sulphate or any other anticonvulsant treatment before admission, other causes of convulsions like epilepsy, meningitis, encephalitis, cerebral tumors, metabolic abnormalities, and those who presented with complications like cerebro-vascular accidents, renal failure, aspiration pneumonitis and hemolysis elevated liver enzymes low platelet count (HELLP) syndrome were excluded from the study. A total of 90 patients were initially recruited in the study, after taking written informed consent, out of which 10 dropped out in due course of time who didn't meet inclusion criteria. Subsequently, the patients were divided into two groups assigning alternate patient in each group (1:1 ratio). Group-1 received low dose while Group-2 received high dose $\mathrm{MgSO}_{4}$ as described further.

\section{History}

Patients' detailed history was taken including age, parity, gestation age, number of convulsions and enquired regarding symptoms of impending eclampsia i.e., headache, blurring of vision, epigastric pain, dizziness. Any past history of hypertension or eclampsia in previous pregnancy was elicited.

\section{Clinical examination}

Included general physical and obstetric examination to assess anemia, degree of oedema and level of consciousness. BMI was calculated along with cardiovascular and respiratory system examination. All relevant investigations were done which included routine antenatal tests, liver function tests, renal function tests, coagulation profile, complete urine examination and fundus examination.

An intravenous access using a wide bore cannula was established and either of the two regimens started. Hourly urine output was measured by indwelling urinary catheter along with half hourly monitoring of pulse, BP, temperature, respiration and fetal heart sounds. In addition, recommended supportive measures were provided to eclamptic patients' i.e., lateral decubitus, protective mouth gag, oxygen inhalation at the rate of $61 /$ min, suctioning and avoidance of external stimulus.

\section{Antihypertensive measures}

Injection Labetalol slow intravenous over 10-15 minutes was given in recommended doses when BP readings were $>160 / 110 \mathrm{~mm}$ of $\mathrm{Hg}$. Tab Nifedipine at $10-30 \mathrm{mg}$ was added when BP was not controlled by Labetalol alone.

\section{Anticonvulsant measures}

Dhaka regimen and Pritchard regimen was given in Group-1 and Group-2 respectively as follows:

Group 1: Loading dose $4 \mathrm{gm}$ of $20 \% \mathrm{MgSO}_{4}$ was given slowly intravenous over 10 minutes with $3 \mathrm{gm}$ of $50 \%$ $\mathrm{MgSO}_{4}$ intramuscularly in both buttocks making a fullloading dose of $10 \mathrm{gm}$.

Maintenance dose: $2.5 \mathrm{gm}$ of $50 \% \mathrm{MgSO}_{4}$ was given intramuscular on alternate buttock every 4 hours till 24 hours after last fit or delivery whichever was later.

Group 2: Received high dose $\mathrm{MgSO}_{4}$ at loading dose of $14 \mathrm{gm}$ which included $4 \mathrm{gm}$ of $20 \%$ slow intravenous over 10 minutes and $5 \mathrm{gm}$ of $50 \% \mathrm{MgSO}_{4}$ intramuscular in both buttocks followed by maintenance dose of $5 \mathrm{gm}$ of $50 \% \mathrm{MgSO}_{4}$ intramuscular on alternate buttock every 4 hours till 24 hours after the last fit or delivery whichever occurred later.

Parameters to be monitored in both regimens before next dose of $\mathrm{MgSO}_{4}$ were:

1. Deep tendon reflexes should be present

2. Respiratory rate $>16 / \mathrm{min}$

3. Urine output $>30 \mathrm{ml} / \mathrm{hour}$ 
If convulsions recur after initial loading dose, a repeat dose of $2 \mathrm{gm}$ intravenously was given and on further recurrence, it was considered to be a failure.

\section{Obstetric examination and management}

Per abdomen was done to assess fetal lie, presentation, fetal heart sounds, to rule out intrauterine growth retardation (IUGR) and per vaginal examination was conducted to know Bishop's score. Termination of pregnancy was done in all patients and mode of termination was planned according to gestational age, fetal status and Bishop's scoring. For vaginal delivery, induction with prostaglandins followed by augmentation with injection (Oxytocin) was done in poor Bishop's score of less than 6. In patients with good Bishop's score of more than 6 , only augmentation of labor was done. Lower section caesarian section (LSCS) was done for all relevant obstetric indications.

\section{Outcome measures}

Primary outcome was to measure effectiveness of both regimens for control and prevention of convulsions. Secondary outcome measure was maternal and neonatal morbidity/mortality as depicted by side-effects and Apgar score at 1 and 5 minutes respectively.

\section{Statistical analysis}

Data thus obtained were entered in Microsoft excel sheet and then transferred to SPSS version 21. Discrete data was expressed as frequency and percentages. Continuous data were summarized as numbers, mean with standard deviation. The data in both the groups were compared using chi-square test and $\mathrm{P}$ value of less than 0.05 was taken to be statistically significant.

\section{RESULTS}

Out of 90 patients initially recruited in the study, 80 were finally enrolled with a response rate of $88.8 \%$. Mean age of Group-1 was $24.90 \pm 4.02$ years and that of Group-2 was $25.67 \pm 3.79$ years. Most of the patients were primigravida in both groups $(70 \%$ versus $52.5 \%)$. Mean gestation age of Group-1 was $36.40 \pm 3.42$ weeks whereas of Group-2 was $37.00 \pm 2.97$ weeks. The difference was statistically non-significant (Table 1).

There were unbooked $75 \%$ cases in Group-1 and 65\% cases in Group-2. The baseline systolic and diastolic BP and urinary albumin is shown in Table 2.

Table 1: Patient's characteristics in both groups.

\begin{tabular}{|c|c|c|c|c|}
\hline Age (in years) & $\begin{array}{l}\text { Dhaka } \\
\text { n (\%) }\end{array}$ & $\begin{array}{l}\text { Pritchard } \\
\mathrm{n}(\%)\end{array}$ & Chi-square & $P$ value \\
\hline$<20$ & $2(5.0)$ & $2(5.0)$ & \multirow{6}{*}{0.654} & \multirow{6}{*}{0.884} \\
\hline $20-25$ & $17(42.5)$ & $14(35)$ & & \\
\hline $25-30$ & $16(40.0)$ & $17(42.5)$ & & \\
\hline$\geq 30$ & $5(12.5)$ & $7(17.5)$ & & \\
\hline Total & $40(100.0)$ & $40(100.0)$ & & \\
\hline Mean \pm S.D. & $24.90 \pm 4.02$ & $25.67 \pm 3.79$ & & \\
\hline \multicolumn{3}{|l|}{ Parity } & & \\
\hline Primigravida & $28(70)$ & $21(52.5)$ & & \\
\hline Multigravida & $12(30)$ & $19(47.5)$ & & \\
\hline Total & $40(100)$ & $40(100.0)$ & & \\
\hline \multicolumn{3}{|c|}{ Gestational age (in weeks) } & \multirow{6}{*}{1.193} & \multirow{6}{*}{0.551} \\
\hline$<32$ & $4(10.0)$ & $2(5)$ & & \\
\hline $32-36$ & $9(22.5)$ & $7(5)$ & & \\
\hline$>36$ & $27(67.5)$ & $31(90)$ & & \\
\hline Total & $40(100.0)$ & $40(100)$ & & \\
\hline Mean \pm S.D. & $36.40 \pm 3.42$ & $37.00 \pm 2.97$ & & \\
\hline \multicolumn{3}{|l|}{ BMI $\left(\mathrm{kg} / \mathrm{m}^{2}\right)$} & \multirow{7}{*}{3.981} & \multirow{7}{*}{0.137} \\
\hline$<19.8$ & $24(60)$ & $19(47.5)$ & & \\
\hline $19.8-26$ & $14(35)$ & $21(52.5)$ & & \\
\hline $26-29$ & $2(5)$ & 0.0 & & \\
\hline$>29$ & 0 & 0.0 & & \\
\hline Total & $40(100)$ & $40(100.0)$ & & \\
\hline Mean \pm S.D. & $19.58 \pm 2.48$ & $19.93 \pm 1.40$ & & \\
\hline
\end{tabular}


Table 2: Baseline blood pressure and urinary albumin.

\begin{tabular}{|c|c|c|c|c|}
\hline Systolic BP(mm of Hg) & $\begin{array}{l}\text { Dhaka } \\
\text { n (\%) }\end{array}$ & $\begin{array}{l}\text { Pritchard } \\
\text { n }(\%)\end{array}$ & Chi-square & $P$ value \\
\hline$<160$ & $15(37.5)$ & $14(35)$ & \multirow{5}{*}{2.218} & \multirow{5}{*}{0.330} \\
\hline $160-180$ & $23(57.5)$ & $26(65)$ & & \\
\hline$>180$ & $2(5)$ & 0 & & \\
\hline Total & $40(100)$ & $40(100)$ & & \\
\hline Mean \pm S.D. & $160.37 \pm 14.12$ & $159.80 \pm 9.40$ & & \\
\hline \multicolumn{3}{|l|}{ Diastolic BP(mm of Hg) } & \multirow{6}{*}{3.879} & \multirow{6}{*}{0.144} \\
\hline$<90$ & $1(2.5)$ & 0 & & \\
\hline $90-110$ & $15(37.5)$ & $23(57.5)$ & & \\
\hline$>110$ & $24(60)$ & $17(42.5)$ & & \\
\hline Total & $40(100)$ & $40(100)$ & & \\
\hline Mean \pm S.D. & $110.05 \pm 9.53$ & $109.55 \pm 8.80$ & & \\
\hline \multicolumn{3}{|l|}{ Urinary albumin } & \multirow{6}{*}{1.537} & \multirow{6}{*}{0.674} \\
\hline Nil & $4(10)$ & $5(12.5)$ & & \\
\hline Trace & $6(15)$ & $6(15)$ & & \\
\hline $1+$ & $14(35)$ & $18(45)$ & & \\
\hline$\geq 2+$ & $16(40)$ & $11(27.5)$ & & \\
\hline Total & $40(100)$ & $40(100)$ & & \\
\hline
\end{tabular}

Trace: $0.15-0.3 \mathrm{~g} / \mathrm{l} ; 1+: 0.3-1 \mathrm{~g} / 1 ; \geq 2+:>1 \mathrm{~g} / 1$

Table 3: Type of eclampsia and frequency of convulsions.

\begin{tabular}{|c|c|c|c|c|}
\hline Type of eclampsia & $\begin{array}{l}\text { Dhaka } \\
\text { n }(\%)\end{array}$ & $\begin{array}{l}\text { Pritchart } \\
\text { n }(\%)\end{array}$ & Chi-square & $P$ value \\
\hline IE & 14 & 35.0 & \multirow{4}{*}{0.580} & \multirow{4}{*}{0.748} \\
\hline APE & 19 & 47.5 & & \\
\hline PPE & 7 & 17.5 & & \\
\hline Total & 40 & 100.0 & & \\
\hline \multicolumn{5}{|l|}{ No. of convulsions } \\
\hline$<2$ & $19(47.5)$ & $14(35)$ & \multirow{4}{*}{2.958} & \multirow{4}{*}{0.228} \\
\hline $2-5$ & $21(52.5)$ & $24(60)$ & & \\
\hline$>5$ & 0 & $2(5)$ & & \\
\hline Total & $40(100)$ & $4(100)$ & & \\
\hline
\end{tabular}

IE: Impending eclampsia; APE: Antepartum eclampsia; PPE: Postpartum eclampsia.

Antepartum eclampsia was the most common type of eclampsia among groups accounting to $47.5 \%$ and $55 \%$ respectively. Most patients had 2-5 convulsions at the time of presentation (52.5\% versus 60\%) (Table 3).

Table 4: Dose of magnesium sulphate.

\begin{tabular}{|lllll|}
\hline Group & Mean & S.D & $\begin{array}{l}\text { P } \\
\text { value }\end{array}$ & Significance \\
\cline { 1 - 3 } Dhaka & $23.75 \mathrm{gm}$ & 2.71 & & \\
Pritchard & $41.35 \mathrm{gm}$ & 4.76 & & HS \\
\hline
\end{tabular}

There was a statistically significant difference in the doses of $\mathrm{MgSO}_{4}$ required for control of fits $(\mathrm{p}<0.001)$ as shown in (Table 4). Convulsions were controlled in $97.5 \%(n=39)$ in Group-1 and $100 \%(n=40)$ in Group-2 and results were comparable $\left(x^{2}=1.013 ; \mathrm{p}=0.314\right)$.
There was one case of recurrence in Group 1 which was shifted to Group-2 while no patient had recurrence in Group-2. LSCS was the most common mode of delivery in both groups $(62.5 \%$ versus $57.5 \%)$.

One patient in Group-1 had caesarian hysterectomy due to associated placenta accreta. $4(10 \%)$ patients in Group1 had loss of deep tendon reflexes as compared to $11(27.5 \%)$ in Group 2 and the difference was statistically significant $(\mathrm{p}=0.045)$.

One patient in Group-2 had severe $\mathrm{MgSO}_{4}$ toxicity, as evidenced by respiratory depression and timely ventilator support saved her. There was no maternal mortality in Group 1 but one patient in Group 2 died due to HELLP syndrome and pulmonary oedema. All other side-effects were comparable in both the groups (Table 5). 
Table 5: Maternal outcome.

\begin{tabular}{|c|c|c|c|c|}
\hline Mode of delivery & $\begin{array}{l}\text { Dhaka } \\
\text { n (\%) }\end{array}$ & $\begin{array}{l}\text { Pritchard } \\
\text { n (\%) }\end{array}$ & Chi-square & P value \\
\hline VD & $11(27.5)$ & $14(35)$ & \multirow{4}{*}{0.586} & \multirow{4}{*}{0.746} \\
\hline Forceps delivery & $4(10)$ & $3(7.5)$ & & \\
\hline LSCS & $25(62.5)$ & $23(57.5)$ & & \\
\hline Total & $40(100)$ & $40(100)$ & & \\
\hline \multicolumn{5}{|l|}{ Convulsions } \\
\hline Controlled & $39(97.5)$ & $40(100)$ & \multirow{3}{*}{1.013} & \multirow{3}{*}{0.314} \\
\hline Recurrent & $1(2.5)$ & 0 & & \\
\hline Total & $40(100)$ & $40(100)$ & & \\
\hline \multicolumn{5}{|l|}{ Side-effects } \\
\hline Loss of knee jerk & $4(10)$ & $11(27.5)$ & 4.021 & 0.045 \\
\hline Oliguria & $3(7.5)$ & $4(10)$ & 0.157 & 0.692 \\
\hline PPH & $3(7.5)$ & $5(12.5)$ & 0.556 & 0.456 \\
\hline Resp. depression & 0 & $2(5)$ & 2.051 & 0.152 \\
\hline Pulmonary edema & 0 & $1(2.5)$ & 1.013 & 0.314 \\
\hline Cerebral edema & 0 & $2(5)$ & 2.051 & 0152 \\
\hline HELPP & $1(2.5)$ & $1(2.5)$ & 0.00 & 1.00 \\
\hline \multicolumn{5}{|c|}{ BP on first post-delivery day } \\
\hline Mean diastolic BP & $90.20 \pm 9.80$ & $86.90 \pm 9.27$ & - & 0.126 \\
\hline Maternal mortality & 0 & $1(2.5)$ & 1.013 & 0.314 \\
\hline
\end{tabular}

VD: Vaginal delivery, LSCS: Lower segment caesarian section, HELLP: Hemolysis elevated liver enzymes low platelet count

Table 6: Neonatal outcome.

\begin{tabular}{|c|c|c|c|c|}
\hline $\begin{array}{l}\text { Baby weight } \\
\text { (in kg) }\end{array}$ & $\begin{array}{l}\text { Dhaka } \\
\text { n (\%) }\end{array}$ & $\begin{array}{l}\text { Pritchard } \\
\text { n (\%) }\end{array}$ & Chi-square & $P$ value \\
\hline$<2$ & $7(17.5)$ & $7(17.5)$ & \multirow{5}{*}{1.668} & \multirow{5}{*}{0.434} \\
\hline $2-2.5$ & $14(35)$ & $9(22.5)$ & & \\
\hline$>2.5$ & $19(47.5)$ & $24(60)$ & & \\
\hline Total & $40(100)$ & $40(100)$ & & \\
\hline Mean \pm S.D. & $2.45 \pm 0.789$ & $2.47 \pm 0.821$ & & \\
\hline \multicolumn{3}{|c|}{ Apgar (at 1 minute) } & \multirow{7}{*}{1.540} & \multirow{7}{*}{0.673} \\
\hline $8-10$ & $22(55)$ & $18(45)$ & & \\
\hline 6-7 & $13(32.5)$ & $18(45)$ & & \\
\hline $4-5$ & $2(5)$ & $1(2.5)$ & & \\
\hline $0-3$ & $3(7.5)$ & $3(7.5)$ & & \\
\hline Total & $40(100)$ & $40(100)$ & & \\
\hline Mean \pm S.D. & $7.00 \pm 2.23$ & $6.75 \pm 2.17$ & & \\
\hline \multicolumn{3}{|c|}{ Apgar (5 minutes) } & \multirow{7}{*}{0.214} & \\
\hline $8-10$ & $34(85)$ & $35(87.5)$ & & \multirow{6}{*}{0.898} \\
\hline $6-7$ & $3(7.5)$ & $2(5)$ & & \\
\hline $4-5$ & 0 & 0 & & \\
\hline $0-3$ & $3(7.5)$ & $3(7.5)$ & & \\
\hline Total & $40(100)$ & $40(100)$ & & \\
\hline Mean \pm S.D. & $7.92 \pm 2.35$ & $7.83 \pm 2.35$ & & \\
\hline
\end{tabular}

It was observed that patient receiving Dhaka regimen had poor control of post-delivery diastolic BP as compared to Pritchard regimen. Neonatal outcome in terms of Apgar score at 1 minute and 5 minute was also comparable in both groups. There was one perinatal death among Group 1 (Table 6).

\section{DISCUSSION}

$\mathrm{MgSO}_{4}$ is used as different regimens in different parts of the world. Pritchard regimen is the most widely used regimen all over the world. Despite its efficacy, narrow therapeutic index is always a cause of concern due to its 
toxicity. The present study and others by Begum et al and Seth et al reported more side-effects with high dose $\mathrm{MgSO}_{4}$ in Pritchard regimen i.e., absence of deep tendon reflexes more as compared to Dhaka regimen. In our study, the mean total dose of $\mathrm{MgSO}_{4}$ for Dhaka regimen was $23.75 \pm 2.71 \mathrm{gm}$, which is significantly lower as compared to Pritchard regimen $(41.35 \pm 4.76 \mathrm{gm})$ with $\mathrm{p}$ value $<0.001$. Similarly, Sharma et al also reported statistically lower incidence of loss of deep tendon reflexes with Dhaka regimen and Jana et al, found total dose of $\mathrm{MgSO}_{4}$ to be $23.9 \pm 4.3 \mathrm{gm}$ during collaborative eclampsia trial $(\mathrm{P} \leq 0.001) .{ }^{11,12}$ Sahu et al, in her study found that the number of doses given in Dhaka regimen

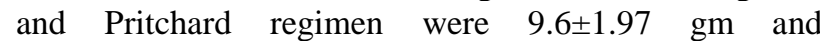
$9.04 \pm 1.69 \mathrm{gm}$, respectively. Total cumulative dose was $31.5 \pm 4.94 \mathrm{gm}$ in Dhaka regimen and 54.2 \pm 8.47 (39-64) in Pritchard regimen. ${ }^{13}$ In the study conducted by Begum et al, Seth et al and Chaudhary et al mortality with Pritchard regimen was higher $(5.02 \%, 7.7 \%$ and $5 \%$ respectively) than those on Dhaka regimen $(0 \%, 4.45 \%$ and $3.3 \%$, respectively). ${ }^{1,9,14}$ However, in our study no mortality was seen among those treated with Pritchard regimen but one death was reported with second regimen. It was observed that patients treated with Dhaka regimen had poor control of diastolic BP as compared to Pritchard regimen although the difference was not statistically significant. This observation was not elaborated in any previous studies to the best of our knowledge. Indian women have low weight and height as well as body mass index (BMI) than women from western countries. Low body weight decreases the volume distribution of magnesium and is recommended to decrease the standard dose for Indian population and overall cost of treatment, which is an important hindrance in achieving the universal health for all, where the availability and cost of injectable $\mathrm{MgSO}_{4}$ is scarce and expensive.

\section{CONCLUSION}

The study concludes that Dhaka regimen is as effective as Pritchard regimen in control of fits and should be incorporated as an alternative in patients of low BMI in population of developing countries and low income groups where there is deficient staff for monitoring. Thus, Dhaka regimen virtually eliminates the risk of $\mathrm{MgSO}_{4}$ toxicity.

Funding: No funding sources

Conflict of interest: None declared

Ethical approval: The study was approved by the Institutional Ethics Committee

\section{REFERENCES}

1. Seth S, Nagrath A, Singh DK. Comparison of low dose, single loading dose and standard Pritchard regimen of magnesium sulphate in ante-partum eclampsia. Anatol $\mathbf{J}$ Obstet Gynecol. 2010;1(1):1-4.

2. Bangal VB, Purushottam A, Giri, Satyajit P Gavhane. A study to compare the efficacy of low dose magnesium sulphate regime with Pritchard regime in eclampsia. Int J Biomed Adv Research. 2012;3(1):53-7.

3. Ministry of Health and Family Welfare, India. Annual Report. NewDelhi; 2005:105-111. Available at: http://mohfw.nic.in/WriteReadData/1892s/6960144509 Annual\%20Report\%20to\%20the\%20People\%20o n\%20Health.pdf. Accessed on December, 2011.

4. Tukur J. The use of magnesium sulphate for the treatment of severe preeclampsia and eclampsia. Ann African Med. 2009;8(2):76-80.

5. Arango MF, Bainbridge D. Magnesium for acute traumatic brain injury. Cochrane Database of Systematic Reviews 2008(4):cd005400.

6. Smith JM, Lowe RF, Fullerton J, Currie SM, Harris L, Felker-Kantor E. An integrative review of the sideeffects related to the use of magnesium sulfate for preeclampsia and eclampsia management. BMC Pregnancy Childbirth. 2013;13:34.

7. Pritchard JA. The use of magnesium sulphate in preeclampsia eclampsia. J Reprod Med. 1979;23:107.

8. Sardesai SP, Patil A, Maira S, Patil U. Low dose magnesium sulphate therapy for eclampsia and imminent eclampsia: Regime tailored for Indian women. Int J Gynecol Obstet. 2000;70:45-6.

9. Begum R, Begum A, Johanson R, Ali MN, Akhter S. A low dose "Dhaka" magnesium sulphate regime for eclampsia. Acta Obstet Gynecol Scand. 2001;80(11):998-1002.

10. Begum MR, Begum A, Quadir E. Loading dose versus standard regime of magnesium sulfate in the management of eclampsia: A randomized trial. J Obstet Gynaecol. 2002;28(3):154-9.

11. Sharma A, Gupta KB, Nigam A, Pathania K. Comparison of low dose Dhaka regimen of magnesium sulphate with standard Pritchard regimen in eclampsia. Int J Reprod Contracept Obstet Gynecol. 2016;5:39548.

12. Jana N, Dasgupta S, Das AK, Santra D, Samanta B. Experience of a low-dose magnesium sulfate regimen for the management of eclampsia over a decade. Int $\mathbf{J}$ Gynaecol Obstet. 2013;122:13-7.

13. Sahu L, Singh S, Tempe A, Koner BC. A randomized comparative study between low-dose magnesium sulphate and standard dose regimen for management of eclampsia. Int J Reprod Contracept Obstet Gynecol. 2014;3:79-86

14. Chowdhury JR, Chowdhury S, Bhattacharya N, Biswas $\mathrm{PK}$. Comparison of intramuscular magnesium sulfate with low dose intravenous magnesium sulfate regimen for treatment of eclampsia. J Obstet Gynaecol Res. 2009;35(1):119-2.

Cite this article as: Bhagat N, Bedi PK, Pal D, Saini A. Therapeutic efficacy of low dose (Dhaka regimen) versus high dose (Pritchard regimen) magnesium sulphate for management of eclampsia and impending eclampsia. Int J Reprod Contracept Obstet Gynecol 2018;7:2333-8. 